\title{
The influence of the scientific approach learning model on the learning outcomes of Buddhism and students' creative thinking skills
}

\author{
Ni Putu Sukmaliani ${ }^{1}$, Tjhia Khie Khiong ${ }^{2}$, Endang Sri Rejeki ${ }^{3}$ \\ ${ }^{1}$ SMP Negeri Uggulan Doremi, Denpasar, Indonesia \\ 2,3 Department of Buddhist Education, Sekolah Tinggi Ilmu Agama Buddha Smaratungga, \\ Boyolali, Indonesia
}

\section{ABSTRACT}

The study aims to analyze the effect of the learning model with a scientific approach on the learning outcomes of Buddhism and students' creative thinking skills. The study Employing quantitative research, this study carries out a pre-experimental design with one group pretest-posttest design. The research population is SMP Negeri Uggulan Doremi students, and the samples are the grade VIIA students in the 2020/2021 academic year. The instruments used are science learning outcomes tests and creative thinking skills tests. Descriptive statistics and T-test analyze data on learning outcomes and creative thinking skills. The results show that there is a significant difference in (1) learning outcomes between students who were taught using the direct instruction model and students who were taught using the scientific approach $(\mathrm{p}<0.05)$, and (2) students' creative thinking skills between students who were taught using the direct instruction model and students who are taught using the scientific approach $(\mathrm{p}<0.05)$. This study proves that the scientific approach is an effective learning model to improve student learning outcomes and creative thinking skills.

\section{ARTICLE INFO}

\section{Keywords:}

Buddhism; scientific approach; learning outcomes; creative thinking skills

\section{Article History:}

Received: Nov 27th 2021

Revised: Dec $12^{\text {th }}, 2021$

Accepted: Dec 20th 2021

Published: Dec 30th 2021

\section{How to Cite in APA Style:}

Sukmaliani, N. P., Tjhia, K. K., Endang, S. R. (2021). The influence of the scientific approach learning model on the learning outcomes of Buddhism and students' creative thinking skills. Smaratungga: Journal of Education and Buddhist Studies, 1(2), 1-11. doi: $10.53417 /$ sjebs.v1i2.52

\section{Introduction}

The Indonesian government revised the policy in the field of education in 2013. The policy revision replaces the Education Unit Level Curriculum (Kurikulum Tingkat Satuan Pendidikan or KTSP) into the 2013 Curriculum. The reasons for developing the 2013 curriculum can be viewed from public perception, development of knowledge and pedagogy, and negative student behavior. The public's perception is that the previous curriculum focused on cognitive aspects, the student burden was too heavy, and character development was not maximized. Complete knowledge development must also pay attention to neurology, psychology, and observation. In

*Corresponding author: sukma.liani@yahoo.com

Published by Center of Research and Publication of Smaratungga Buddhist Collage

This is an open access article under the CC BY-NC 4.0 (https://creativecommons.org/licenses/by-nc/4.0/) https://doi.org/10.53417/sjebs.v1i2.52 
Ni Putu Sukmaliani, Thia Khie Khiong, Endang Sri Rejeki
Smaratungga: Journal of Education and Buddhist Studies, Vol. 1, No. 2, December 2021

addition, the phenomenon of negative adolescent behavior that tends to increase is also a reference that the previous curriculum has not succeeded in developing student character.

In the 2013 curriculum, the learning design used is a scientific approach. The scientific approach is learning, which consists of observing activities (to identify things which are wanted to know), formulating questions (and formulating hypotheses), trying/collecting data (information) with various techniques, associating/analyzing/processing data (information), and drawing conclusions and communicating the results of the conclusions (Sari \& Supriyono, 2015). The learning process designed for learning with a scientific approach aims to make students able to construct concepts, laws, or principles through observation, formulate problems, present or formulate hypotheses, collect data, use many techniques to analyze data, make conclusions, and communicate concepts or principles which is found (Kuniasih, I \& Berlin, S, 2014).

The principles of the scientific approach are (1) students are facilitated to find out, (2) students learn as learning resources, (3) the learning process uses a scientific approach, (4) competency-based learning, (5) integrated learning, (6) learning which emphasizes divergent answers that have multidimensional truths, (7) applied skills-based learning, (8) improving balance, continuity between soft skills and hard skills, (9) learning that prioritizes cultivating and empowering students as lifelong learners, (10) learning which takes place at home, school, and in the community, (11) the use of technology information and communication technology to improve the efficiency and effectiveness of learning, (12) recognition of individual differences and the cultural background of students, and (13) a fun and challenging learning atmosphere (Subaeri et al., 2016).

Buddhism and Character Education are subjects in the learning process that shape the attitudes, knowledge, and skills of students in practicing the teachings of Buddhism, which are carried out at all levels of education. In the 2013 curriculum, Buddhism and character education are in the first clump, a group of religious subjects and noble characters. In general, this subject group has functions to develop the ability of students to strengthen faith and piety to God Almighty, have a noble character, and respect adherents of other religions. As one of the subjects in the 2013 curriculum, it is appropriate to apply a scientific approach to Buddhism. The characteristics of the scientific approach to the teaching of Buddhism are active student learning patterns, two-way interaction, collaboration, and attention to the potential of students.

Based on the researchers' observations, the teaching of Buddhism is mainly done with a conventional approach. Buddhist teachers only present the material by lecturing, and students become listeners. Learning interactions tend to occur in one direction, from teacher to student. Thus, students only become passive learners. Conditions like this make the learning objectives of Buddhism not optimal.

Research shows that many students who get learning outcomes of Buddhism are below the Minimum Completeness Criteria or Kriteria Ketuntasan Minimal (KKM) (Utaminingsih et al., 2015). The low learning outcomes of Buddhism are caused by learning that is not optimal and tends to be teacher-centered. Hence, the students are less able to develop their knowledge. Therefore, a paradigm shift in Buddhist learning must be carried out immediately. 
One of the lessons that can be suggested is a scientific approach. The scientific approach is one of the student-centered learning approaches. Students discover and develop their knowledge independently, and the teacher acts as a facilitator. The scientific approach consists of five stages: observing, asking questions, collecting data, processing information, and communicating. The scientific approach also stimulates students to conduct two-way interactions between students and teachers. Thus, learning becomes more fun and meaningful, impacting optimal learning outcomes.

Student creativity in Indonesia is also still low. According to Tungasadah (Rachmawati \& Rohaeti, 2018), Hans Jellen and Klaus Urban from the University of Utah and the University of Hannover researched student creativity in eight countries in 2005. The countries studied were the Philippines, United States of America, England, Germany, India, China, Indonesia, and Zulu. As a result, the creativity of Indonesian students is ranked 8th, which is the last. One of the reasons is that learning in Indonesia is less innovative and only uses the lecture method. Learning with the lecture method causes students to become passive learners, and the result is that it is challenging to develop their creativity.

The scientific learning approach allows students to develop their creativity and become active learners who play an active role in the learning process. Students develop knowledge and solve problems given by the teacher. Thus, students' thinking skills will be trained, especially creative thinking. Creative thinking can help students to be able to see a problem from various perspectives and generate various ideas (Floren, 2016). There are four aspects to creative thinking: fluency, flexibility, authenticity, and detail (Zubaidah et al., 2017). The ability to think creatively requires proper planning of the learning process (Sarwindah, 2013).

The study shows that learning with a scientific approach can be applied to teaching Buddhism to improve student learning outcomes and creative thinking skills. This research was conducted to empirically prove the influence of scientific approach learning on the learning outcomes of Buddhism and the creative thinking skills of the students of SMP Negeri Uggulan Doremi.

\section{Method}

This research uses the quantitative method and is classified as a pre-experimental design, a study that has not been a natural experiment because external variables influence the dependent variable (Sugiyono, 2017). The research design is a onegroup pretest-posttest design with pre-test, treatment, and post-test steps. The study was conducted at SMP Negeri Uggulan Doremi with a sample of VIII grade students who adhered to Buddhism in the 2020/2021 academic year.

The variables of this research are the scientific approach model and the direct learning model as independent variables and learning outcomes and creative thinking skills as the dependent variable. Creative thinking skills data were obtained using a creative thinking skills questionnaire instrument, and learning outcomes data were measured by learning outcomes questions. Before being tested, the validity and reliability of the instruments are determined. All instrument items have a validity coefficient of more than equal to 0.3 as a valid criterion requirement. The reliability of learning outcomes is 0.773 , while the reliability of the creative thinking 
skills questionnaire was 0.930 . Both of these instruments have reliability in the high and very high categories.

Data analysis used descriptive analysis. Data on learning outcomes and creative thinking skills are categorized based on the Benchmark Reference Assessment criteria below:

Table 1. Guidelines for conversion of benchmark reference assessment

\begin{tabular}{lll}
\hline No & Interval & Criteria \\
\hline 1 & $91-100$ & Very Good \\
\hline 2 & $81-90$ & Good \\
\hline 3 & $71-80$ & Sufficient \\
\hline 4 & $<71$ & Less \\
\hline
\end{tabular}

The normalized gain score is used to calculate the extent of the increase in each variable. According to Nurcahyati (2012), the formula for calculating the normalized gain score is as follows:

$$
\operatorname{Gain}\left(g \text {-factor) }=\frac{S_{f}-S_{i}}{S_{m}-S_{i}}\right.
$$

Note:

$\mathrm{Sf}=$ final score (post-test)

$\mathrm{Si}=$ initial score $($ pre-test $)$

$\mathrm{Sm}=$ ideal maximum score

Tabel 2. Score gain criteria

\begin{tabular}{lll}
\hline No & Criteria & Category \\
\hline 1 & $\mathrm{~g}>0,7$ & High \\
\hline 2 & $0,7<\mathrm{g}>0,3$ & Average \\
\hline 3 & $\mathrm{G}<0,3$ & Low \\
\hline
\end{tabular}

A hypothesis test was carried out using the dependent sample T-test technique. Before testing the hypothesis, the prerequisite tests are carried out, including the normality test and the homogeneity of variance test. The prerequisite and hypothesis tests were carried out with a significance value of 0.05 .

\section{Findings}

\section{Data on student learning outcomes}

Student learning outcomes data from the classroom where the research was conducted are presented in Table 3.

Table 3. Student learning outcomes in the research classroom

\begin{tabular}{lllll}
\hline No & Learning Model & $\begin{array}{l}\text { Highest } \\
\text { Score }\end{array}$ & Lowest Score & Average \\
\hline 1 & Direct learning model & 54 & 24 & 37 \\
\hline 2 & The scientific approach learning model & 95 & 84 & 91 \\
\hline
\end{tabular}


Based on the data in Table 3, it can be seen that the average score of student learning outcomes after being taught using the direct learning model is 37 , and if categorized based on the LAP scale, it is classified as more minor. After being given learning activities with the scientific approach learning model, the average student learning outcome becomes 91 and is very good.

Score classification of student learning outcomes based on the number of students and the Benchmark Reference Assessment scale. The classification of student learning outcomes is shown in Table 4.

Table 4. Classification of student learning outcomes

\begin{tabular}{llllll}
\hline No & Criteria & \multicolumn{2}{l}{ Direct Learning Model } & \multicolumn{2}{l}{$\begin{array}{l}\text { Scientific Approach Learning } \\
\text { Model }\end{array}$} \\
\cline { 3 - 6 } & & f & $\%$ & f & $\%$ \\
\hline 1 & $92-100$ & 0 & $0 \%$ & 11 & $55 \%$ \\
\hline 2 & $82-91$ & 0 & $0 \%$ & 9 & $45 \%$ \\
\hline 3 & $72-81$ & 0 & $0 \%$ & 0 & $0 \%$ \\
\hline 4 & $<72$ & 20 & $100 \%$ & 0 & $0 \%$ \\
\hline
\end{tabular}

The data in Table 4 shows that after learning using the direct learning model, the score of student learning outcomes mostly in the fewer criteria, after being given learning activities with the scientific approach learning model, the score of student learning outcomes in the fewer criteria decreases, even to $0 \%$.

After that, the normalized gain score is calculated to determine the increase in student learning outcomes after being taught with the scientific approach learning model. Here are the results of the calculation:

$$
\begin{aligned}
\operatorname{Gain}(g-\text { factor }) & =\frac{91-37}{100-37} \\
& =0,85
\end{aligned}
$$

Based on the results of the calculations, it can be stated that the increase in student learning outcomes scores after being taught with the scientific approach learning model is relatively high.

\section{Creative thinking skills data}

The data on students' creative thinking skills after being given learning using direct learning models and scientific approaches are presented in Table 5.

Table 5. Students' creative thinking skills data

\begin{tabular}{lllll}
\hline No & Learning Model & Highest Score & Lowest Score & Average \\
\hline 1 & Direct learning model & 48 & 35 & 43 \\
\hline 2 & $\begin{array}{l}\text { The scientific approach learning } \\
\text { model }\end{array}$ & 96 & 75 & 87 \\
\hline
\end{tabular}

The data presented in Table 5 shows that the average score of students' creative thinking skills after being taught using the scientific approach learning model is higher than that of the direct learning model. 
Ni Putu Sukmaliani, Thia Khie Khiong, Endang Sri Rejeki
Smaratungga: Journal of Education and Buddhist Studies, Vol. 1, No. 2, December 2021

Then, the test scores of students' creative thinking skills were also classified after being taught using the direct and scientific learning models. The classification is based on the LAP scale. The results of the classification can be seen in Table 6 .

Table 6. Classification of students' creative thinking skills

\begin{tabular}{llllll}
\hline No & Criteria & \multicolumn{2}{l}{ Direct Learning Model } & \multicolumn{2}{l}{$\begin{array}{l}\text { Scientific Approach Learning } \\
\text { Model }\end{array}$} \\
\cline { 3 - 6 } & & f & $\%$ & $\mathrm{f}$ & $\%$ \\
\hline 1 & $92-100$ & 0 & $0 \%$ & 5 & $25 \%$ \\
\hline 2 & $82-91$ & 0 & $0 \%$ & 12 & $60 \%$ \\
\hline 3 & $72-81$ & 0 & $0 \%$ & 3 & $15 \%$ \\
\hline 4 & $<72$ & 20 & $100 \%$ & 0 & $0 \%$ \\
\hline
\end{tabular}

Based on the data in Table 6, it can be seen that the score of students' creative thinking skills after being given direct learning is in the lower criteria. Students' creative thinking skills score in excellent, sound, and sufficient criteria when given learning activities with the scientific approach.

The calculation of the normalized gain score is also carried out on the students' creative thinking skill scores. The following is the result of calculating the normalized gain score from the data on students' creative thinking skills:

$$
\text { Gain (g-factor) }=\frac{87-43}{100-43}=0,77
$$

Referring to Table 2, the value of the normalized gain score for creative thinking skills is in the high criteria.

\section{Discussion}

\section{The influence of the scientific approach learning model on student learning outcomes}

This study aims to analyze the effect of the scientific approach learning model on student learning outcomes. This research stage begins with learning in the research class using a direct learning model and continues with learning outcomes tests. After that, students in the research class were taught a scientific approach learning model. Then, students in the research class were given a learning outcome test.

The results of the descriptive analysis showed that the average test scores of students' learning outcomes after being taught using the scientific approach learning model were more significant than those who were taught using the direct learning model. The analysis results are also supported by the hypothesis test results, which state significant differences in learning outcomes between students taught with a scientific approach learning model and students whom a direct learning model teaches. Thus, it can be stated that the scientific approach learning model effectively improves student learning outcomes.

There are several fundamental reasons why the scientific approach learning model effectively improves student learning outcomes. First, the scientific approach is a learning model with a student-centered paradigm. In this learning model, students are the main actors in the learning process. The teacher's role is only as a 
facilitator. Thus, active students in learning activities get many opportunities to learn. Therefore, student learning outcomes are better than students taught using the direct learning model.

Second, the scientific approach is a learning model based on constructivism theory. This theory states that students build (construct) their knowledge in the learning process. Students will find it easier to understand the concepts presented. In addition, when students are allowed to construct their knowledge, students' learning motivation will increase. High learning motivation will improve the learning outcomes (Dewi et al., 2014).

Third, the syntax of the scientific approach learning model can develop aspects of student learning outcomes in the cognitive domain, which includes memory, understanding, application, analysis, and creation. The initial stage of the scientific approach learning model is observing. When students do observations, they will relate what they have observed with their knowledge, and hence students' ability to remember will develop. Furthermore, there is an interaction between students and teachers in the questioning stage by asking questions about what is observed. After that, students can answer the question without blaming the teacher. Students will be trained to understand the observations and apply their knowledge in this phase. The third phase is collecting data. In this phase, students in groups collect various data types to answer the questions posed. In this case, students must understand the question well and then analyze the data and concepts needed to answer the question. The fourth phase is the data association. Students select and relate the collected data and concepts to answer the questions in this phase. Students must understand the data and concepts obtained, analyze, and apply the concepts to answer existing problems. The last is the communicating phase. In this phase, students conclude the answers to the problems given, present them in front of their friends, and defend the answers they find. When students can make conclusions, they can create a new concept or understanding of a problem.

The direct learning model has weaknesses. Direct learning is a teachercentered learning model. Thus, the teacher plays an active role in the learning process, making the students passive. The results in the learning process being only a knowledge transfer process, not knowledge discovery. Consequently, the students find it challenging to understand and impact low learning outcomes.

The results of this study are in line with previous research. Simatupang \& Tiarmaida (2015) states that the inquiry learning model significantly influences student learning outcomes in Physics subjects. Dewi's research (2014) reports that the Problem Based Learning (PBL) model effectively improves science learning outcomes for $V$ grade elementary school students. The inquiry learning model, PBL, and scientific approach adhere to the student-centered learning paradigm and are based on constructivism theory.

\section{The effect of the scientific approach-based learning model on creative thinking skills}

The study results show that the scientific approach learning model significantly influences students' creative thinking skills. It can be seen from the descriptive analysis that the average score of creative thinking skills after being taught with the scientific approach learning model is higher than being taught with a direct learning 
Ni Putu Sukmaliani, Thia Khie Khiong, Endang Sri Rejeki
Smaratungga: Journal of Education and Buddhist Studies, Vol. 1, No. 2, December 2021

model. After being taught using the direct learning model and learning the scientific approach, the average score of students' thinking skills were 43 and 87, respectively.

The results of hypothesis testing strengthened the descriptive analysis. The results of the hypothesis test using the T-test technique show a significant number below 0.05, and hence the alternative hypothesis (Ha), which states "there is a significant difference in creative thinking skills between students who are taught with the scientific approach learning model and those who are taught with the direct learning model" is accepted. Thus, it can be concluded that the scientific approach learning model effectively improves students' creative thinking skills.

The results of this study are in line with the research of (Sugiyastini et al., 2013), which reports that the project-based learning model has a positive effect on students' creative thinking skills in science learning. Rachmawati \& Rohaeti (2018) states that the generative learning model significantly influences students' creative thinking skills.

There are several fundamental reasons why the scientific approach learning model effectively improves students' creative thinking skills. First, the scientific approach is a learning model based on constructivism theory. According to Hardiyasa et al. (2014), learning models based on constructivism can grow students' creative thinking skills. The scientific approach learning model is designed to support students to construct their knowledge through the stages of the learning model.

Second, in the scientific approach learning model, there is a brainstorming activity as a trigger to generate students' ideas by asking as many questions as possible and giving students the freedom to provide answers to the questions given. This activity is in the scientific approach learning model phase, the questioning phase. Students' creative thinking skills can grow when allowed to think and express new ideas freely (Santika, 2016).

Third, the scientific approach learning model stages stimulate students to develop aspects of creative thinking. Aspects of fluent thinking and flexible thinking can be developed by asking many divergent questions and providing opportunities for students to express answers to those questions (Sekar et al., 2015). The is the stage of learning activities in the questioning phase. Fluent and flexible thinking are also developed at the collecting data and communicating stages. At the communicating stage, students are required to think fluently and be flexible in defending their arguments and refuting friends' arguments. Aspects of detailed thinking are trained at the stage of associating data. In this phase, students are required to detail the data needed to answer the questions given by the teacher. In addition, in the data-associating phase, it is also required to develop original thinking skills when making conclusions on the questions made.

The teacher's role in the direct learning model is very dominant. The teacher acts as a transfer of concepts to students and facilitators. The opportunity for students to propose ideas and be directly involved in learning activities is minimal. It makes it difficult for students to develop students' creative thinking skills. Moreover, training students' creativity can support active learners or main learning activities (Munandar, 2002).

The implication of the research is the optimization of the use of the scientific approach as an alternative learning model in improving learning outcomes and 
creative thinking skills. Therefore, teachers, mainly Buddhist and Character Education subjects, can use the scientific approach learning model or similar learning models to improve learning outcomes and increase student creativity.

The obstacle found throughout this research was applying the scientific approach learning model. Students in the research class who were previously accustomed to a passive learning culture became confused with the learning activities which was carried out. Students were not used to asking questions, collecting data, and communicating findings. Researchers overcame this by guiding students and giving rewards to actively learning students.

\section{Conclusion}

Based on the discussion of this research, it can be concluded that there are significant differences in learning outcomes between students who are taught with the scientific approach learning model and students who are taught using a direct learning model. The study results also show a significant difference in students' creative thinking skills using the scientific approach and direct learning models.

The suggestions given by the researchers regarding the results of this study are that the scientific approach learning model can be used as an alternative in improving learning outcomes and creative thinking skills. On the other hand, schools and teachers should facilitate and condition a learning environment that can grow student creativity both inside and outside the classroom, and this research is limited to studying the effectiveness of the scientific approach learning model in improving learning outcomes and creative thinking skills. Further research is necessary to examine the effectiveness of this learning model in improving learning outcomes in other aspects, such as learning activities, critical thinking skills, or other relevant aspects.

\section{References}

Arfentha Sari, S. (2015). Penerapan model pembelajaran kooperatif tipe Nht (Numbered Heads Together) pada materi fluida statik berorientasi kurikulum 2013. Jurnal Inovasi Pendidikan Fisika (JIPF), 4(1), 22-25. doi: 10.36709/jipfi.v6i2.17109

Dewi, N. L. K. L., Suwatra, W., \& Rati, N. W. (2014). Pengaruh model problem based learning terhadap hasil belajar tematik di SDN Segugus $1 \mathrm{Kec}$. Marga. E-Journal MIMBAR PGSD Universitas Pendidikan Ganesha Jurusan PGSD (Vol. 2 No. 1 Tahun 2014), 2(1), 2. doi: 10.23887/jjpgsd.v2i1.3773

Floren, M. R. (2016). Penerapan metode problem solving untuk meningkatkan hasil belajar siswa dalam pembelajaran IPS di kelas IV SDN Pojok 03 Kabupaten Tulungagung. PENA SD Uurnal Pendidikan Dan Pembelajaran Anak Sekolah Dasar), 2(1), 9-22. https://core.ac.uk/download/pdf/328198471.pdf

HARDIYASA, I., Suma, M., \& Sadia, M. (2014). Pengaruh model siklus belajar 5e terhadap keterampilan berpikir kreatif dan motivasi berprestasi siswa. Jurnal Pendidikan Dan Pembelajaran IPA Indonesia, 4(1).

Rachmawati, D., \& Rohaeti, E. (2018). Pengaruh model pembelajaran sains, teknologi, dan masyarakat terhadap kemampuan berpikir kritis dan motivasi belajar peserta didik. Jurnal Pendidikan Matematika Dan Sains, 6(1), 29-39. 
Santika, S. (2016). Pengaruh penggunaan pembelajaran kooperatif tipe STAD berbantuan program Geometer's Sketchpad terhadap kemampuan berpikir kreatif matematik siswa SMP. JP3M (Jurnal Penelitian Pendidikan Dan Pengajaran Matematika), 2(1), 49-60. doi: 10.37058/jp3m.v2i1.155

Sarwindah. (2013). Kajian pemilihan software desain grafis untuk pembelajaran dengan metode AHP studi kasus SMK Muhammadiyah 9. Seminar Nasional Teknologi Informasi Dan Multimedia 2013, 39-44.

Sekar, D. K. S., Pudjawan, K., \& Margunayasa, I. G. (2015). Analisis kemampuan berpikir kreatif dalam pembelajaran IPA pada siswa kelas IV Universitas Pendidikan Ganesha. E-Journal PGSD Universitas Pendidikan Ganesha Jurusan PGSD, 3(1), 1-11.

Simatupang, S., \& Tiarmaida. (2015). Pengaruh model pembelajaran inkuiri terhadap hasil belajar siswa pada materi pokok listrik dinamis di kelas X semester II SMA Negeri 8 Medan T.P. 2013/2014. Jurnal Ikatan Alumni Fisika Universitas Negeri Medan, 1(1), 34-41. doi: 10.24114/jiaf.v1i1.2693

Subaeri, Rahayu, S., \& Marfuah, S. (2016). Pendekatan saintifik dalam mengeksplisitkan hakikat sains (NOS) (pp. 688-696). Prosiding Seminar Nasional Pendidikan IPA Pascasarjana Universitas Negeri Malang.

Sugiyastini, W., Sudana, D. N., \& Suartama, I. K. (2013). Pengaruh model pembelajaran berbasis proyek terhadap kemampuan berfikir kreatif siswa pada mata pelajaran IPA Kelas V SD Gugus V Banjar. Jurnal Mimbar PGSD Undiksha, 1(1), 1-11.

Utaminingsih, S., Hasyim, A., \& Tupari. (2015). Peningkatan hasil pembelajaran praktik vipassana bhavana menggunakan metode demonstrasi di Sekolah Menengah Atas Bodhisattva Bandar Lampung. Jurnal Teknologi Informasi Komunikasi Pendidikan, 1(5), 1-28.

Zubaidah, S., Fuad, N. M., Mahanal, S., \& Suarsini, E. (2017). Improving students' creative thinking skills through Differentiated Science Inquiry integrated with a mind map. Journal of Turkish Science Education, 14(4), 77-91. doi: 10.12973/tused.10214a 